\title{
ENERGY-EFFICIENT SHAPING OF CONTEMPORARY BUILDINGS AND THEIR SURROUNDINGS AS AN ESSENTIAL ELEMENT OF MODERNIZATION OF BUILT-UP AREAS
}

\author{
Stanisław BOCHEŃSKI ${ }^{1}$, \\ Anna BOCHEŃSKA-SKAŁECKA ${ }^{2}$, Tadeusz KUCZYŃSKI ${ }^{3}$ \\ ${ }^{1}$ Wroclaw University of Technology, Wrocław, Poland, \\ ${ }^{2}$ Wroclaw University of Environmental and Life Sciences Faculty of Environmental \\ Engineering and Geodesy, Wrocław, Poland \\ ${ }^{3}$ University of Zielona Góra, Zielona Góra, Poland
}

\begin{abstract}
A comprehensive design of a building along with the development of a surrounding land may counterbalance the tendency of housing estates comprising houses built on the basis of "ready-made projects" - which have no references to the existing urban tissue and which do not create a new one. In the first place, the energy intensity of buildings using the so-called passive methods should be lowered, and only then active systems should be applied, considering economic balance. The problem should be considered from two different perspectives i.e. for intensively and for less urbanised areas. The article results in the formulation of guidelines for energy-efficient modernization of contemporary buildings and their surroundings.
\end{abstract}

Keywords: energy-efficient architecture, modernization of contemporary buildings, passive and active systems.

\footnotetext{
${ }^{1}$ Corresponding author: Wroclaw University of Technology, Faculty of Architecture, B. Prus st 53/55, 50-317 Wrocław, Poland, e-mail: stanisław.bochenski@pwr.edu.pl

${ }^{2}$ Corresponding author: Wroclaw University of Environmental and Life Sciences Faculty of Environmental Engineering and Geodesy, Pl. Grunwaldzki 24; 50-363 Wrocław, Poland, e-mail: anna.bochenska-skalecka@up.wroc.pl

${ }^{3}$ Corresponding author: University of Zielona Góra, Faculty of Civil and Environmental Engineering, Z. Szafrana st 1, 65-516 Zielona Góra, Poland, e-mail: t.kuczynski@iis.uz.zgora.pl
} 


\section{INTRODUCTION}

The tradition of architectural design of buildings to suit them to climate and functional-utility conditions has been practised for many years. Before the invention of modern heating, ventilation and air conditioning systems, the residents' comfort was assured mainly by designing the shape and the envelope of a building in such a way to take advantage of the "pluses" of the climate and to reduce its "minuses". The contemporary reliance on installation systems blurs the understanding of the many alternative ways in which the shape and the envelope of a building may fulfil this intermediate function. The energy crises, which occurred in the twentieth century, raised the need for energy conservation and encouraged designers to look for new elements and applications or to rediscover and exploit the forgotten traditions. The first stage of the research of the issue was launched in the 1960's and concerned mainly analyses of the climate impact on a building [1] ${ }^{4}$. At the moment, two trends are observed in the design and construction of buildings supplied by the so-called unconventional (alternative) sources of energy, which are defined as:

- "innovative": objects are designed basing on theoretical data, or even intuitively, where the design basis was an established energetic objective or the originality of architectural solution or else installations (passive and active methods). Investments were realised regardless to costs, or the costs were important to a lesser extent (experimental buildings),

- "practical": developed in the early 1980's, thanks to mass-producing devices (e.g. layered air collectors thermosiphons etc.), insulation materials, or entire installations. It aimed at reducing energy consumption obtained in a conventional manner and using the energy savings in other areas of the economy.

Generally, there are two trends of shaping the discussed buildings:

- "geomorphic": trying to apply "the recent advances in energy-related issues" to a traditionally understood form, function and structure of buildings which for a variety of reasons have a restricted capacity for energy savings - "innovative": where the maximum energy benefits significantly influenced the shape of a building.

\footnotetext{
${ }^{4}$ It presents in detail the analysis of the impact of the US climate on its architecture. The main weakness of this study is that it considers the impact of various climatic factors irrespectively one from another, without taking into account the comprehensive impact of these factors on architectural solutions, as well as on the human body [1].
} 


\section{LAND USE AND URBAN PLANNING}

Reducing the negative impact of the increase in energy consumption can be achieved by changing the structure of primary energy use, changing the energy production technologies, and also by integrating energy systems within a settlement unit, as well as by the optimization of management of energy generation and transmission. It is also crucial to increase the share of alternative energy in the overall energy balance [10].

Energy systems of settlement units (electricity and heating) are not interrelated, which often makes energy production and distribution inefficient. Polish energy sector is, and will be in the near future, based on coal and nuclear power. The carried out analyses showed that the excessive centralization of the fuel and energy systems on scattered built-up areas greatly increases the expenditure incurred on transportation, or distribution of fuels and energy ${ }^{5}$. It seems that equipping micro-settlements (50-250 people) with non-conventional energy systems can be more economic than using traditional ones. Moreover, it can prevent their liquidation and suppress population migration to larger centres. The foremost goal of construction, regardless of location, is to reduce energy demand, supplied both conventionally and alternatively. It is envisaged that it will be possible to save conventional energy regardless of location. It seems that the reduction of the scale of complexes of residential areas is a necessity, regardless to the size of a construction task. This results not only from the residents' psychophysical features, which need to be taken into account, but also from their lifestyles. It is expected that air heating and low-temperature water heating systems will most probably be used in buildings constructed on lowintensively developed areas (in terms of "floor space ratio"). Electricity or gas distributed by network (possibly biogas) will be used to heat water and to prepare food. In our climatic conditions, the application of passive methods may reduce the energy needed by the construction sector. Significant energy savings or profits from unconventional sources may be achieved using the so-called mixed techniques, which will be composed of active installations.

\section{ARCHITECTURE DESIGN}

It should be remembered that designers of energy efficient buildings reveal and use diverse range of subject knowledge and equipment (e.g. power of computers, software, etc.). However, it should be expected that design and research centres, equipped with specialized instrumentation and staff, will

\footnotetext{
${ }^{5}$ A number of generally known studies on the subject were carried out [6].
} 
perform model design elaborations based on multi-variant specialist calculations using numerical techniques. They may help to elaborate model procedures of conduct and patterns of approximate calculations used later on a mass scale.

Efforts to reduce heating demand for the construction sector can be divided into three groups:

1. heat losses reduction in terms of the structure:

- greater compactness of the building,

- increasing the insulation of the building envelope,

- variable nature (surface) of window and door openings,

- zoning of premises according to desired parameters of microclimate

("buffers"), or even reducing heated space in unfavourable climatic conditions,

- proper shaping of the immediate surroundings of the building to provide wind protection,

- associating the building's heating and ventilation systems

2. increasing the so-called heat gains by using direct, indirect, mixed or semiactive systems of energy generation: solar energy, heat from the ground and in unique locations by:

- formation of "solar windows" and planes which would capture, concentrate, reflect and direct solar radiation,

- increasing: capacities and thermal stability of selected (mostly internal) parts of a building,

- shaping the interior space so that it will be possible to take advantage of natural or forced convection for heating (e.g. hybrid power systems, or varying position of the neutral axis).

- constructing buildings which are partly or completely laid.

3. the use of the so-called active systems of energy generation from

unconventional sources, such as:

- various types of solar collectors, together with installations,

- wind turbines,

- heat pumps, or other.

The so-called dynamic nature of a building, in relation to environmental factors, should become the preferred direction of energy saving measures $[3,5]$. It involves taking into account the following issues in the design process:

- a moderate increase in insulation of the building envelope,

- variability of usable area,

- variability of ways of the use of premises,

- associated with the mentioned above - the correction of residents' habits and their active participation in reducing energy exploitation losses. 
The current heating systems, operating in short intervals and resulting in alternating periods of heating and cooling the premise, as well as the heat flow between the rooms are problems which are growing in importance and which are not included in traditionally utilized buildings.

Some authors promote design support sets for energy-efficient architectural design, useful at the early stages of the design process. They consist of three parts: a set of patterns of conduct, a schema of patterns, the hierarchy of measures (objectives). Solving problems usually involves resolving a number of small (minor) situations leading to a collective end. The search for formulas (typical solutions for individual parts of a problem) seems to be a useful method. Another proposal to systematize the process of building design is the method developed by one of the authors of this publication, i.e. "A method of architectural design taking into account energy rationale" which is based on two fundamental assumptions:

- equivalence between the energy objective and the traditional (architectural) objective of the designing process, i.e. raising the importance of the energy objective,

- examining the issues of thermal balance (energy balance) for all components of the building, i.e.: the interiors, the outer partition as well as the building immediate vicinity [4].

Designing methods: "languages of patterns”, “... taking into account energy rationale" (Bocheński S.) and a number of others presented at conferences and in subject publications, are similar in terms of basic concepts. They differ mainly in:

- the method of valuing the objectives,

- the applied methods to perform specialized optimization calculations (e.g. with the use of numerical methods),

- the evaluation manners and the methods for standardization of the evaluation scales (e.g. quantifiable and non-quantifiable criteria).

The proposed method does not exclude the use of others (e.g. the ones which use computer techniques) [10].

The clarification of the objective is a necessary process because the number of objectives is relatively large. Virtually, a model of a building having a plurality of elements which, in turn, may have a number of dimensions may be created for each of objective. In addition, in many cases, mutual interactions (configurations) will occur between the elements. There are many attempts to formalize the so-called configuration strategies, but knowledge on this subject is still insufficient [8]. Currently, the economical evaluation criteria seem to be relatively simple in use: 
- the calculation of the reduction of energy losses or gains due to the introduced specific solutions,

- the calculation of the costs of applying innovations and modifications to the power supply system and the determination of the efficiency of the design and textures to the area directly adjacent to the building, we can also save a certain amount of energy. Materials with bright colours should be used in the surroundings to reflect sunlight onto the building. Dark colours should be introduced to absorb sunlight and to increase the temperature solution, or the so-called ultimate reimbursement $[6,9]$.

Conditioning the shape of the object due to the wind directions and designing wind shields in the building's immediate vicinity (i.e. greens, or the so-called spoilers) can significantly reduce heat losses due to infiltration. The effects of colour and texture of the surface on absorption are generally well known. According to research by F. Heck, this aspect of a building facade may bring 2$8 \%$ profits of heating energy [2]. By using materials of appropriate colours

\section{SUMMARY AND CONCLUSIONS}

On the basis of the research carried out in the recent years, as well as completed designs and the implemented projects (in Poland), the following general conclusions may be drawn:

1. The presented issues affecting the energy savings in the heating period are interrelated and there is no clear method of conduct in order to obtain maximum energy savings.

2. The particular methods for energy saving depend, more or less, on extra energy inputs.

3. It is necessary to examine the parameters of structural elements of the building (walls, ceilings) for maximum accumulation and utilization of solar energy.

4. Principles of roof formation should take into account their possible use as air collectors (thermosiphons) or roof fanlights. It seems appropriate to examine and compare the performance of both systems.

5. There are no studies on the principles of shaping the projection area of a building, its volume, the number of storeys, external surfaces and the ranges of an optimal ratio of these values, for buildings with passive solar systems.

6. The worldwide used passive solar systems should be examined in detail for their efficiency and the ranges of the applicability of each of them in Polish climate conditions.

7. Taking into account the use of solar energy, principles for the design of window openings (their shape, size and direction of facing) should consider 
the floor surface and the room volume. Also, amendments to the normative lighting requirements for buildings should be introduced. The above analysis should also refer to "Trombe wall" and "greenhouse outbuildings". The research and analysis of methods used for calculating the gains from solar radiation indicate the desirability and advantages of simplified methods when the radiation effect is clearly visible in spring and autumn, whereas the accuracy of calculations does not affect significantly the energy balance of the building (in terms of uncontrolled leakage problems and their impact on the microclimate of the interior). The desirability of considering and calculating heat gains from sunlight in the period of lowest insolation, i.e. winter, may be questionable. The impact of infiltration appears to be so changeable that it can be omitted, and simultaneously, the gains from sunlight can be ignored. Buffer zones may reduce the influence of infiltration, which is possible e.g. in a building of a dynamic character. The selection of optimal solutions taking into account the energy consumption at all stages of implementation may be the objective for further detailed work, carried out with the use of numerical calculations, as well as the analyses of examples of design and research. Considering a number of projects and their implementations in terms of energy efficiency, it is noted that in view of a large number of variables, the designer often gets lost both in determining the optimum objective and the measures needed to achieve it [6]. Therefore it is proposed to use methods for architectural design which apply "energy rationale" rules (previously discussed) or others. Apart from the evaluation of specific design solutions it seems to be necessary to determine the effect of non-conventional energy techniques on construction in the following areas: socio-cultural, economic, or in terms of shaping a microenvironment bioclimate [3]. Changes to the criteria of values, ways of thinking and others pertain also, and perhaps above all, to the designers of architecture. It is expected that the spatial approach to issues of energy balance and changing the character of a building in relation to its surroundings (from static to dynamic), will become new paradigms of design. For, as B. Fuller (one of the most famous contemporary architects) once said: "All that is material that surrounds us is a form of energy, and all that energy is subject to a beautiful recirculation in the universe. This is us, people who do short circuits. (...) The production of one gallon of kerosene costs one million US dollars spent on heat, electricity and pressure. We burn our savings. We must learn to live according to our energy possibilities" [2].

\footnotetext{
${ }^{6}$ The structure and performance of the "Trombe wall" and the "greenhouse outbuildings" were discussed in several publications, including $[2,4,5,6]$.
} 


\section{REFERENCES}

1. Aronin J. E.: Climate and Architecture, N. York, Rainhold 1953.

2. Balcomb D. J., Gordon T. H.: Design and performance of passive solar building, Hungary, ISES-Solar Word Congres 1987.

3. Bocheńska-Skałecka A.: Model solution - an essential, initial designing tool for shaping energy-efficient building development and land development, Procedia Engineering by Elsevier, ISSN: 1877-7058 2011.

4. Bocheński S.: The influence onkonventionalen energy sources in building design, Pecs, Hungary, INF.CONF PLEA 1986.

5. Bocheński S.: Dynamic character of a building and its energy balance as new paradigms of designing, Ljubljana, SLOSE - Passive Solar Architectura 1988.

6. Bocheński S.: Podstawy projektowania budynków mieszkalnych uwzględniajace ich dynamiczny charakter $w$ stosunku do działających nań czynników środowiskowych dla osiagnięcia maksymalnych korzyści energetycznych, temat $n r 1.28$ CPBR 02.21 „Energobudynek” etapy 1-5, Warszawa, IPPT PAN Warszawa, Raporty WA PWr 1990-1993.

7. Klasik A.: Optymalna struktura przestrzenna a rozwój regionalny, Warszawa, PWE 1974.

8. Kozielecki J.: Psychologiczna teoria decyzji, Warszawa, PWN 1975.

9. Marks W.: Optymalizacja $w$ budownictwie energooszczędnym, Białystok, Polska Energetyka Słoneczna nr 12003.

10. Misztal G., Ziębicki P., Benysek G., Kuczyński T.: Analiza wymagań technicznych $i$ eksploatacyjnych dla budynków przy zasilaniu ze scentralizowanych źródet ciepta, Warszawa, Przegląd Budowlany $\mathrm{nr}$ $6 / 2014$.

11. Olgay V.: Design with climate, N. Yersay 1963.

\section{ENERGOOSZCZĘDNE KSZTAŁTOWANIE WSPÓŁCZESNEJ \\ ZABUDOWY I JEJ OTOCZENIA, JAKO NIEZBĘDNY ELEMENT MODERNIZACJI OBSZARÓW ZABUDOWY}

\section{Streszczenie}

Kompleksowe rozwiązanie budynku wraz $\mathrm{z}$ zagospodarowaniem terenu zabudowy stanowiłoby przeciwwagę dla tendencji "osiedli domów z projektów gotowych" - nie powiązanych $\mathrm{z}$ istniejącą tkanką urbanistyczną i nie tworzących nowej. W pierwszej kolejności winno się obniżyć energooszczędność budynków wykorzystując metody 
znane jako tzw. pasywne, a dopiero następnie i uwzględniając rachunek ekonomiczny, stosować systemy aktywne. Problem należy rozpatrywać dwutorowo, tzn. dla obszarów: intensywnej zabudowy i mniej zurbanizowanych. Efektem artykułu jest sformułowanie wytycznych dla energooszczędnej modernizacji współczesnej zabudowy i jej otoczenia

Słowa kluczowe: architektura energooszczędna, modernizacja współczesnej zabudowy, systemy pasywne i aktywne.

Editor received the manuscript: 15.01.2015 